\title{
Meta-analysis
}

\section{Energy requirements of adult cats}

\author{
Emma N. Bermingham ${ }^{1 *}$, David G. Thomas ${ }^{2}$, Penelope J. Morris ${ }^{3}$ and Amanda J. Hawthorne ${ }^{3}$ \\ ${ }^{1}$ Food, Metabolism and Microbiology Section, AgResearch Limited, Grasslands Research Centre, Tennent Drive, Palmerston North \\ 4442, New Zealand \\ ${ }^{2}$ Centre for Feline Nutrition, Massey University, Palmerston North 4442, New Zealand \\ ${ }^{3}$ Waltham Centre for Pet Nutrition, Waltham on the Wolds LE14 4RT, UK
}

(Received 22 April 2009 - Revised 15 October 2009 - Accepted 16 October 2009 - First published online 26 January 2010)

A meta-analysis was carried out in order to establish the energy requirements of adult cats. Publications that identified cat body weight (BW) were used to generate allometric relationships between energy requirements and BW of healthy adult cats, using log-log linear regression. Energy requirements were expressed in $\mathrm{kcal} / \mathrm{kg} \mathrm{BW}$ to be consistent with those reported by the National Research Council. Mean maintenance energy requirements were 55.1 (SE 1.2) kcal/kg BW (115 treatment groups). Three allometric equations were identified to predict the energy requirements for maintenance of BW in the cat based on BW: light $\left(53.7 \mathrm{kcal} / \mathrm{kg} \mathrm{BW}{ }^{-1.061}\right)$, normal $\left(46 \cdot 8 \mathrm{kcal} / \mathrm{kg} \mathrm{BW}^{-1.115}\right)$ and heavy $(131 \cdot 8 \mathrm{kcal} / \mathrm{kg}$ $\mathrm{BW}^{-0.366}$ ). When reported on lean mass, the allometric equation revealed maintenance requirements were $58.4 \mathrm{kcal} / \mathrm{kg}$ lean mass ${ }^{-1 \cdot 140}$ (adjusted $R^{2}$ 0.694; thirty-six treatment groups). The present review suggests that values for maintenance energy requirements based on BW alone may not be an accurate prediction and more detailed information on the age, sex and neuter status, BW and composition would enhance the ability to interpret the maintenance energy requirements of cats.

Cats: Energy requirements: Allometric equations

While the relationships between energy requirements and age $^{(1,2)}$ and body weight $(\mathrm{BW})^{(3)}$ have been determined in domestic cats, these reports utilised the outcomes of a series of studies in only a single colony of cats. Given the increase in obesity levels in companion animals and the number of recent studies that have investigated this phenomenon, meta-analysis may be an appropriate tool to accurately determine the energy requirements of adult cats. The use of meta-analysis is a powerful method by which the results from multiple independent experiments can be combined to produce more robust results than can be obtained from single experiments alone ${ }^{(4)}$. Combining results from different experiments using statistical meta-analytical methods can reduce the extent that differences in experimental conditions may have an impact on the calculated prediction equations and cause bias. Additionally, meta-analysis can identify factors that may influence these relationships.

Maintenance energy requirements for adult cats have been calculated to be $100 \mathrm{kcal} / \mathrm{kg} \mathrm{BW}^{-0.67}$ for normal-weight, and $130 \mathrm{kcal} / \mathrm{kg} \mathrm{BW}^{-0.4}$ for heavy cats ${ }^{(5)}$. The National Research Council (NRC) ${ }^{(5)}$ highlighted that the literature reporting maintenance energy requirements in adult cats is highly variable. For example, the effects of age on maintenance energy requirements differ markedly among publications, as does the effects of neutering. These effects may be explained by other factors that were not taken into consideration among studies, such as age of the cat or methodology used to determine the cats' energy requirements.

The objective of the present review was to conduct a meta-analysis on the energy requirements for maintaining $\mathrm{BW}$ in adult domestic cats in order to (a) determine predicted changes in energy requirements with weight, and (b) account for factors that may influence these relationships. Initial results have been reported in abstract format in Bermingham et al. ${ }^{(6)}$. For ease of comparison with the $\mathrm{NRC}^{(5)}$, we have reported energy requirements in $\mathrm{kcal} / \mathrm{kg} \mathrm{BW}$.

\section{Materials and methods}

Data classification

Data for the present review on the energy requirements of adult cats were limited to publications reported in English, and published from 1933 to 2009. These search criteria

Abbreviations: BW, body weight; DLW, doubly-labelled water; FE, feeding experiment; IC, indirect calorimetry; ME, metabolisable energy; NRC, National Research Council.

* Corresponding author: Dr Emma Bermingham, fax +64 6351 8003, email emma.bermingham@agresearch.co.nz 


\begin{tabular}{|c|c|c|c|c|c|c|c|c|c|c|c|}
\hline Reference & Sex & Method & $\begin{array}{l}\text { Length of study } \\
\text { (d) }{ }^{*}\end{array}$ & $\begin{array}{l}\text { Cats } \\
(n)\end{array}$ & $\begin{array}{l}\text { Mean age } \\
\text { (years) }^{*}\end{array}$ & $\begin{array}{l}\text { Mean BW } \\
(\mathrm{kg})^{\star}\end{array}$ & Mean fat $(\%)^{*}$ & $\begin{array}{c}\text { Mean ME (kcal/kg } \\
\text { BW })^{\star}\end{array}$ & $\begin{array}{l}\text { Modified } \\
\text { Atwater? }\end{array}$ & $\begin{array}{c}\text { Mean ME } \\
\text { (kcal/kg } \\
\text { fat-free mass) }\end{array}$ & Used in dataset \\
\hline \multirow[t]{2}{*}{ Appleton et al. ${ }^{(35)}$} & Mix & $\mathrm{FE}$ & 42 & 16 & & $6.3(\mathrm{SD} 1.3)$ & $42 \cdot 2$ & $40.4($ SD 5.8$)$ & & 71.3 & Yes \\
\hline & Mix & $\mathrm{FE}$ & 42 & 16 & & $6.3(\mathrm{SD} 1.3)$ & 43.2 & 47.1 (SD 15.9) & & $84 \cdot 1$ & Yes \\
\hline Aub et al. ${ }^{(36)}$ & Mix & IC & & 13 & & 3.7 & & 55.0 (SD 11.0) & & & Yes \\
\hline Ballevre et al. ${ }^{(37)}$ & Mix & DLW & & 3 & $7 \cdot 0$ & 4.4 & $22 \cdot 7$ & $55.0($ SD 1.0$)$ & & $53 \cdot 2$ & Yes \\
\hline Benedict ${ }^{(38)}$ & Mix & IC & & 30 & & $2 \cdot 8$ & & 70.0 & & & Yes \\
\hline \multirow[t]{5}{*}{ Burger et al. ${ }^{(39)}$} & Mix & $\mathrm{FE}$ & 21 & 18 & & $3 \cdot 8$ & & $49 \cdot 3$ & Yes & & Yes \\
\hline & Mix & FE & 21 & 19 & & $3 \cdot 7$ & & $49 \cdot 2$ & Yes & & Yes \\
\hline & Mix & $\mathrm{FE}$ & 21 & 18 & & 3.6 & & 41.7 & Yes & & Yes \\
\hline & Mix & FE & 21 & 18 & & $4 \cdot 1$ & & $50 \cdot 8$ & Yes & & Yes \\
\hline & Mix & $\mathrm{FE}$ & 21 & 19 & & $4 \cdot 1$ & & 54.9 & Yes & & Yes \\
\hline Caldwell $^{(9)}$ & Mix & IC & & 14 & & & & $83.0(\mathrm{SD} 7.5)$ & & & No - no BW \\
\hline Carpenter ${ }^{(40)}$ & Mix & IC & & 5 & & 3.5 & & 56.0 (SD 7.5) & & & No \\
\hline \multirow[t]{7}{*}{ Earl \& Smith ${ }^{(9)}$} & Mix & $\mathrm{FE}$ & 21 & 7 & & $6 \cdot 3$ & & $42 \cdot 2$ & Yes & & Yes \\
\hline & Mix & $\mathrm{FE}$ & 21 & 26 & & $5 \cdot 8$ & & 47.9 & Yes & & Yes \\
\hline & Mix & FE & 21 & 22 & & $2 \cdot 8$ & & $75 \cdot 2$ & Yes & & Yes \\
\hline & Mix & FE & 21 & 53 & & $5 \cdot 3$ & & $52 \cdot 4$ & Yes & & Yes \\
\hline & Mix & $\mathrm{FE}$ & 21 & 48 & & 4.8 & & $54 \cdot 7$ & Yes & & Yes \\
\hline & Mix & $\mathrm{FE}$ & 21 & 24 & & $3 \cdot 8$ & & $67 \cdot 3$ & Yes & & Yes \\
\hline & Mix & $\mathrm{FE}$ & 21 & 36 & & $3 \cdot 3$ & & $76 \cdot 4$ & & & Yes \\
\hline \multirow{5}{*}{$\begin{array}{l}\text { Edtstadtler- } \\
\text { Pietsch }^{(11)} \dagger\end{array}$} & $\mathrm{F}$ & FE & & 30 & & 3.9 & & $65 \cdot 0(S D 16 \cdot 0)$ & & & Yes \\
\hline & M & $\mathrm{FE}$ & & 4 & & & & $67.0($ SD 14.0) & & & No - no BW \\
\hline & M & $\mathrm{FE}$ & & 7 & 1.0 & & & $100.0($ SD 26.0$)$ & & & No - no BW \\
\hline & NF & $\mathrm{FE}$ & & 33 & & $4 \cdot 1$ & & $56.0($ SD 16.0) & & & Yes \\
\hline & NM & $\mathrm{FE}$ & & 63 & & $5 \cdot 2$ & & $55.0($ SD 14.0) & & & Yes \\
\hline \multirow[t]{4}{*}{ Fettman et al. ${ }^{(25)}$} & M & $\mathrm{FE}$ & 30 & 6 & 1.8 & $5.8(\mathrm{SD} 0.8)$ & & 43.3 & Yes & & Yes \\
\hline & NM & $\mathrm{FE}$ & 30 & 6 & 1.8 & $6.0($ SD 0.4$)$ & & $43 \cdot 2$ & Yes & & Yes \\
\hline & $\mathrm{F}$ & FE & 30 & 6 & 1.8 & 3.4 (SD 0.2) & & $61 \cdot 2$ & Yes & & Yes \\
\hline & NF & $\mathrm{FE}$ & 30 & 6 & 1.8 & $3.6(\mathrm{SD} 0.2)$ & & 58.2 & Yes & & Yes \\
\hline \multirow[t]{10}{*}{ Flynn et al. ${ }^{(23)}$} & $\mathrm{F}$ & $\mathrm{FE}$ & 42 & 5 & 1.2 & 2.9 (SD 0.2) & & 85.5 & Yes & & Yes \\
\hline & $\mathrm{F}$ & $\mathrm{FE}$ & 42 & 5 & 1.2 & 2.9 (SD 0.2$)$ & & 57.0 & Yes & & Yes \\
\hline & $\mathrm{F}$ & $\mathrm{FE}$ & 42 & 5 & 1.2 & $2.9(\mathrm{SD} 0.2)$ & & 68.4 & Yes & & Yes \\
\hline & $\mathrm{F}$ & $\mathrm{FE}$ & 42 & 5 & 1.2 & 2.9 (SD 0.2$)$ & & $67 \cdot 3$ & Yes & & Yes \\
\hline & $\mathrm{F}$ & $\mathrm{FE}$ & 42 & 5 & & 2.9 (SD 0.2) & & 68.4 & Yes & & Yes \\
\hline & NF & FE & 42 & 10 & & $3 \cdot 1$ & & $45 \cdot 6$ & Yes & & Yes \\
\hline & NF & $\mathrm{FE}$ & 42 & 10 & $1 \cdot 2$ & $2 \cdot 8$ & & 84.4 & Yes & & Yes \\
\hline & NF & $\mathrm{FE}$ & 42 & 10 & 1.2 & 2.8 & & 44.5 & Yes & & Yes \\
\hline & NF & FE & 42 & 10 & 1.2 & $2 \cdot 8$ & & $74 \cdot 1$ & Yes & & Yes \\
\hline & NF & FE & 42 & 10 & 1.2 & $2 \cdot 8$ & & $46 \cdot 7$ & Yes & & Yes \\
\hline \multirow[t]{4}{*}{ Green $^{(41)}$} & Mix & IC & & 10 & 3.2 (SEM 0.6 ) & 3.8 (SEM 0.3$)$ & $9 \cdot 6$ (SEM 2.4$)$ & $56 \cdot 6$ (SEM 14.3 ) & & $56 \cdot 6$ & Yes \\
\hline & Mix & IC & & 10 & $3.2(\operatorname{SD~} 0.6)$ & $3.9($ SD 0.3$)$ & $12.9(\mathrm{SD} 2.8)$ & $59.9($ SD 21.5) & & 59.9 & Yes \\
\hline & Mix & IC & & 10 & $3.2(\mathrm{SD} 0.6)$ & $4.2(\mathrm{SD} 0.3)$ & 16.6 (SD 4.0) & 65.4 (SD 14.3) & & 65.4 & Yes \\
\hline & Mix & IC & & 10 & $3.2($ SD 0.6$)$ & $4.2(\mathrm{SD} 0.3)$ & 11.7 (SD 3.0) & 62.5 (SD 16.7) & & 62.5 & Yes \\
\hline \multirow[t]{6}{*}{ Hauschild ${ }^{(42)} \dagger$} & Mix & IC & & 4 & 5.5 & $5 \cdot 8$ & & 39.0 (SD 2.5) & & & Yes \\
\hline & Mix & IC & & 27 & 1.5 & $3 \cdot 8$ & & $50.0($ SD 2.0$)$ & & & Yes \\
\hline & Mix & IC & & 9 & & $3 \cdot 3$ & & $51.0($ SD 1.0$)$ & & & Yes \\
\hline & Mix & IC & & 4 & 4.5 & 4.0 & & $51.0($ SD 2.0$)$ & & & Yes \\
\hline & Mix & IC & & 6 & & $3 \cdot 1$ & & $54.0($ SD 4.0$)$ & & & Yes \\
\hline & Mix & IC & & 5 & & $3 \cdot 2$ & & 55.0 (SD 2.5) & & & Yes \\
\hline
\end{tabular}


WS British Journal of Nutrition

Table 1. Continued

\begin{tabular}{|c|c|c|c|c|c|c|c|c|c|c|c|}
\hline Reference & Sex & Method & $\begin{array}{l}\text { Length of study } \\
\text { (d) })^{\star}\end{array}$ & $\begin{array}{l}\text { Cats } \\
(n)\end{array}$ & $\begin{array}{l}\text { Mean age } \\
\text { (years) }^{*}\end{array}$ & $\begin{array}{c}\text { Mean BW } \\
(\mathrm{kg})^{\star}\end{array}$ & Mean fat $(\%)^{\star}$ & $\begin{array}{c}\text { Mean ME (kcal/kg } \\
\text { BW) })^{\star}\end{array}$ & $\begin{array}{l}\text { Modified } \\
\text { Atwater? }\end{array}$ & $\begin{array}{c}\text { Mean ME } \\
\text { (kcal/kg } \\
\text { fat-free mass) }\end{array}$ & Used in dataset \\
\hline & Mix & IC & & 6 & & 3.3 & & $61.0(\mathrm{SD} 2.0)$ & & & Yes \\
\hline & Mix & IC & & 6 & & 3.9 & & $48.0($ SD 1.0$)$ & & & Yes \\
\hline \multirow{8}{*}{ Hoenig et al. ${ }^{(27)}$} & $\mathrm{F}$ & FE & 28 & 10 & & $3.4(\mathrm{SD} 0.3)$ & & 65.6 (SD 4.1) & & & Yes \\
\hline & M & $\mathrm{FE}$ & 28 & 10 & & $4.0($ SD 0.6$)$ & & 68.3 (SD 4.6) & & & Yes \\
\hline & NF & $\mathrm{FE}$ & 28 & 10 & & $3.4($ SD 0.4$)$ & & 67.9 (SD 2.5) & & & Yes \\
\hline & NF & $\mathrm{FE}$ & 28 & 10 & & $3.5(\mathrm{SD} 0.4)$ & & 60.1 (SD 6.1) & & & Yes \\
\hline & NF & $\mathrm{FE}$ & 28 & 10 & & $3.4(\mathrm{SD} 0.4)$ & & $57.0(\mathrm{SD} 7.7)$ & & & Yes \\
\hline & NM & $\mathrm{FE}$ & 28 & 10 & & $4.0($ SD 0.6$)$ & & 68.2 (SD 4.6) & & & Yes \\
\hline & NM & FE & 28 & 10 & & $4.1($ SD 0.7$)$ & & 69.5 (SD 9.5) & & & Yes \\
\hline & NM & $\mathrm{FE}$ & 28 & 10 & & $4.0(\mathrm{SD} 0.6)$ & & $58.5(\mathrm{SD} 15.6)$ & & & Yes \\
\hline \multirow[t]{8}{*}{ Hoenig et al. ${ }^{(43)}$} & Mix & FE & 112 & 12 & 4.3 (SE 0.4) & 3.4 (SE 0.3) & & 51.6 (SE 4.2) & & & Yes \\
\hline & Mix & $\mathrm{FE}$ & 112 & 12 & $4.3($ SD 0.4$)$ & 3.3 (SD 0.2 ) & & 50.6 (SD 4.5) & & & Yes \\
\hline & Mix & FE & 112 & 12 & $4.3(S D 0.4)$ & $3.3($ SD 0.2$)$ & & 55.4 (SD 6.0) & & & Yes \\
\hline & Mix & $\mathrm{FE}$ & 112 & 12 & $4.3(\mathrm{SD} 0.4)$ & $3.6(\mathrm{SD} 0.2)$ & & 49.3 (SD 3.8) & & & Yes \\
\hline & Mix & $\mathrm{FE}$ & 112 & 16 & $5.1(S D 1.2)$ & $6.6(S D 0.3)$ & & 42.1 (SD 1.4) & & & Yes \\
\hline & Mix & $\mathrm{FE}$ & 112 & 16 & $5.1(\mathrm{SD} 1.2)$ & $6.2(\mathrm{SD} 0.4)$ & & $35.8(\mathrm{SD} 2.0)$ & & & Yes \\
\hline & Mix & $\mathrm{FE}$ & 112 & 16 & $5.1(\mathrm{SD} 1.2)$ & $6.3(S D 0.4)$ & & 41.7 (SD 1.6) & & & Yes \\
\hline & Mix & $\mathrm{FE}$ & 112 & 16 & $5.1(S D 1.2)$ & $6.3($ SD 0.4$)$ & & 38.8 (SD 2.1) & & & Yes \\
\hline \multirow[t]{4}{*}{ Kanchuk et al. ${ }^{(22)}$} & $M$ & DLW & & 5 & 2.0 & 4.6 (SEM 0.1 ) & 8.9 (SEM 0.4$)$ & 75.0 (SEM 4.1 ) & & 82.1 & Yes \\
\hline & M & DLW & & 5 & $2 \cdot 0$ & $4.7($ SD 0.1) & $11.8(S D 1.6)$ & $66.0($ SD 3.3) & & $75 \cdot 7$ & Yes \\
\hline & $\mathrm{M}$ & DLW & & 5 & $2 \cdot 0$ & $4.6(S D 0.2)$ & 9.8 (SD 0.8) & 76.0 (SD 4.8) & & $85 \cdot 3$ & Yes \\
\hline & NM & DLW & & 5 & $2 \cdot 0$ & 4.8 (SD 0.1$)$ & 12.4 (SD 1.7) & 79.0 (SD 8.6) & & $90 \cdot 3$ & Yes \\
\hline Kendall et al. ${ }^{(44)}$ & Mix & $\mathrm{FE}$ & 21 & 6 & & 4.0 & & 66.0 & & & $\begin{array}{l}\text { No - different } \\
\text { diets }\end{array}$ \\
\hline \multirow[t]{5}{*}{ Kienzle et al. ${ }^{(17)}$} & Mix & $\mathrm{FE}$ & 28 & 138 & & $5 \cdot 7$ & & $60.0(\mathrm{SD} 18.0)$ & & & Yes \\
\hline & $\mathrm{F}$ & $\mathrm{FE}$ & 28 & 30 & & $3.9(\mathrm{SD} 1.1)$ & & 72.3 (SD 14.0) & & & Yes \\
\hline & $\mathrm{M}$ & FE & 28 & 12 & & $5 \cdot 1(\mathrm{SD} 2 \cdot 1)$ & & 78.6 (SD 21.0) & & & Yes \\
\hline & NF & $\mathrm{FE}$ & 28 & 33 & & 3.9 (SD 2.1) & & 66.0 (SD 16.0) & & & Yes \\
\hline & NM & FE & 28 & 63 & & $5.1($ SD 1.1$)$ & & 52.7 (SD 24.0) & & & Yes \\
\hline Krehl et al. ${ }^{(12)}$ & Mix & $\mathrm{FE}$ & & & & & & 68.4 & Yes & & No - no BW \\
\hline \multirow{4}{*}{ Laeuger ${ }^{(45)} \dagger$} & NM & IC & & 6 & 0.9 & 5.5 & & $42 \cdot 0$ & & & Yes \\
\hline & M & IC & & 6 & 0.9 & 4.8 & & 49.0 & & & Yes \\
\hline & M & IC & & 6 & 0.8 & $5 \cdot 1$ & & 54.0 & & & Yes \\
\hline & $\mathrm{M}$ & IC & & 6 & 0.8 & $5 \cdot 2$ & & 54.0 & & & Yes \\
\hline $\begin{array}{l}\text { Laflamme \& } \\
\qquad \text { Ballam }^{(13)}\end{array}$ & Mix & $\mathrm{FE}$ & & 113 & & & & 53.0 & & & No - no BW \\
\hline \multirow{3}{*}{ Leray et al. (29) } & Mix & IC & & 8 & $5 \cdot 5$ & $2.9(\operatorname{SD} 0.1)$ & $31 \cdot 3$ & $47 \cdot 3$ (SEM $2 \cdot 2)$ & & $52 \cdot 1$ & Yes \\
\hline & Mix & IC & & 8 & 5.5 & 2.9 (SD 0.1$)$ & 29.5 & $51.4(\mathrm{SD} 4.1)$ & & 52.6 & Yes \\
\hline & Mix & IC & & 8 & 5.5 & $2.9($ SD 0.1$)$ & 27.5 & 52.6 (SD 3.1) & & 58.3 & Yes \\
\hline \multirow[t]{6}{*}{ Lester et al. ${ }^{(30)}$} & NF & $\mathrm{FE}$ & 8 & 6 & $11.0(\mathrm{SD} 3.0)$ & $3.6(\mathrm{SD} 0.6)$ & $16.3(\mathrm{SD} 9.6)$ & 48.5 (SD 6.5) & & $58.2(\mathrm{SD} 7 \cdot 8)$ & Yes \\
\hline & NF & FE & 8 & 6 & 11.0 (SD 3.0) & 3.6 (SD 0.6$)$ & 16.3 (SD 9.6) & $46.7($ SD 5.6$)$ & & 56.0 (SD 6.8) & Yes \\
\hline & NF & IC & & 6 & 11.0 (SD 3.0) & 3.6 (SD 0.6 ) & 16.3 (SD 9.6) & $61.4($ SD 17.1) & & 73.8 & Yes \\
\hline & NM & FE & 8 & 6 & 9.0 (SD 3.0) & $4.5($ SD 0.8$)$ & 10.2 (SD 7.5) & $39.0($ SD 7.6$)$ & & $42 \cdot 8$ (SD $8 \cdot 3$ ) & Yes \\
\hline & NM & FE & 8 & 6 & $9.0($ SD 3.0) & $4.5($ SD 0.8$)$ & $10.2($ SD 7.5$)$ & 47.0 (SD 6.4) & & 51.6 (SD 7.1) & Yes \\
\hline & NM & IC & & 6 & $9.0(\mathrm{SD} 3.0)$ & $4.5(\mathrm{SD} 0.8)$ & $10.2(\mathrm{SD} 7.5)$ & 63.1 (SD 5.9) & & 70.7 & Yes \\
\hline \multirow[t]{4}{*}{ Martin et al. ${ }^{(24)}$} & $\mathrm{F}$ & DLW & & 12 & 1.6 & $4.5(S D 0.1)$ & 30.1 (SD 1.7) & $57.0(\mathrm{SD} 2.0)$ & & $80 \cdot 0$ & Yes \\
\hline & $\mathrm{M}$ & DLW & & 11 & 1.6 & $4.5(S D 0.1)$ & 23.8 (SD 1.0) & 57.0 (SD 2.0) & & 74.0 & Yes \\
\hline & NF & DLW & & 9 & 1.6 & $4.5(\mathrm{SD} 0.1)$ & 35.5 (SD 1.8) & $51.0($ SD 2.0$)$ & & $79 \cdot 0$ & Yes \\
\hline & NM & DLW & & 10 & 1.6 & 4.5 (SD 0.1$)$ & 32.9 (SD 1.7) & $50.0(\operatorname{SD~3.0)}$ & & 74.0 & Yes \\
\hline
\end{tabular}


NS British Journal of Nutrition

Table 1. Continued

\begin{tabular}{|c|c|c|c|c|c|c|c|c|c|c|c|}
\hline Reference & Sex & Method & $\begin{array}{l}\text { Length of study } \\
\text { (d) })^{*}\end{array}$ & $\begin{array}{l}\text { Cats } \\
(n)\end{array}$ & $\begin{array}{l}\text { Mean age } \\
\text { (years) }^{\star}\end{array}$ & $\begin{array}{l}\text { Mean BW } \\
(\mathrm{kg})^{*}\end{array}$ & Mean fat $(\%)^{*}$ & $\begin{array}{c}\text { Mean ME (kcal/kg } \\
\text { BW })^{\star}\end{array}$ & $\begin{array}{l}\text { Modified } \\
\text { Atwater? }\end{array}$ & $\begin{array}{c}\text { Mean ME } \\
\text { (kcal/kg } \\
\text { fat-free mass) }\end{array}$ & Used in dataset \\
\hline \multirow[t]{2}{*}{ Miller \& Allison ${ }^{(14)}$} & Mix & FE & & & & & & 68.4 & Yes & & No - no BW \\
\hline & Mix & FE & & & & & & $96 \cdot 9$ & Yes & & No - no BW \\
\hline \multirow[t]{5}{*}{ Nguyen et al. ${ }^{(46)}$} & $\mathrm{F}$ & DLW & & 6 & & & $29 \cdot 3$ (SEM 3.1) & $57.0($ SEM 3.0$)$ & & & Yes \\
\hline & NF & DLW & & 6 & & & 33.8 (SD 2.3) & $53.0($ SD 3.0$)$ & & & Yes \\
\hline & M & DLW & & 6 & & & 24.6 (SD 1.5) & $59.0(\mathrm{SD} 3.0)$ & & & Yes \\
\hline & NM & DLW & & 6 & $1 \cdot 3$ & & $32.9(\mathrm{SD} 2.1)$ & $55.0($ SD 2.0$)$ & & & Yes \\
\hline & NM & DLW & & 9 & 3.7 & & 28.6 (SD 1.9) & $50.0(\mathrm{SD} 3.0)$ & & & Yes \\
\hline \multirow[t]{3}{*}{ Nguyen et al. ${ }^{(20)}$} & Mix & DLW & & 85 & & $4.2(\mathrm{SE} 1.2)$ & & $54.0($ SE 10.0) & & & Yes \\
\hline & Mix & IC & & 41 & & 6.0 (SD 1.3) & & $29.0($ SD 5.0$)$ & & & Yes \\
\hline & Mix & FE & 21 & 94 & & $4.9(\mathrm{SD} \mathrm{1.1)}$ & & $59.0(\mathrm{SD} 14.0)$ & & & Yes \\
\hline Nguyen et al. ${ }^{(47)}$ & Mix & FE & & 7 & $6 \cdot 2$ & 6.5 & & 29.6 (SEM 1.0) & & & $\begin{array}{l}\text { No - not steady } \\
\text { state }\end{array}$ \\
\hline \multirow[t]{8}{*}{ Nguyen et al. ${ }^{(48)}$} & $\mathrm{F}$ & DLW & & 6 & 0.8 & $2 \cdot 6$ & 18.5 & $52.8(\mathrm{SD} 3.6)$ & & $64 \cdot 8$ & Yes \\
\hline & $\mathrm{F}$ & DLW & & 6 & 0.8 & $2 \cdot 8$ & $21 \cdot 7$ & $62.9($ SD 12.7) & & $80 \cdot 3$ & Yes \\
\hline & M & DLW & & 6 & 0.8 & 3.5 & $20 \cdot 8$ & $49.0(S D 1.7)$ & & 61.9 & Yes \\
\hline & M & DLW & & 6 & 0.8 & 3.9 & $20 \cdot 2$ & 54.7 (SD 5.3) & & $68 \cdot 6$ & Yes \\
\hline & NF & DLW & & 6 & 0.8 & $2 \cdot 8$ & 23.4 & 57.8 (SD 4.3) & & $75 \cdot 5$ & Yes \\
\hline & NF & DLW & & 6 & 0.8 & $2 \cdot 8$ & 23.8 & 68.8 (SD 2.4) & & $90 \cdot 3$ & Yes \\
\hline & NM & DLW & & 6 & 0.8 & 3.5 & $15 \cdot 1$ & 59.3 (SD 9.6) & & $69 \cdot 8$ & Yes \\
\hline & NM & DLW & & 6 & 0.8 & 3.3 & $22 \cdot 6$ & 40.9 (SD 4.1) & & $52 \cdot 8$ & Yes \\
\hline \multirow[t]{2}{*}{ Nguyen et al. ${ }^{(26)}$} & Mix & IC & & 16 & 4.5 & 4.8 & & 39.0 & & & $\begin{array}{l}\text { No - not steady } \\
\text { state }\end{array}$ \\
\hline & Mix & IC & & 16 & 4.5 & $4 \cdot 8$ & & 39.4 & & & $\begin{array}{l}\text { No - not steady } \\
\text { state }\end{array}$ \\
\hline Parkman et al. ${ }^{(32)} \ddagger$ & Mix & FE & 84 & 36 & $4 \cdot 0$ & $5 \cdot 1(\mathrm{SD} 1 \cdot 2)$ & & $62.0(\mathrm{SD} 15.5)$ & & & Yes \\
\hline \multirow[t]{2}{*}{ Peachy et al. ${ }^{(19)}{ }^{+}$} & NF & IC & & 6 & $3.6(\mathrm{SD} 0.9)$ & $3.5(\mathrm{SD} 0.4)$ & & $52.9(\operatorname{SD} 0.4)$ & & $68.0($ SD 12.4) & Yes \\
\hline & NF & IC & & 6 & 12.3 (SD 1.4) & $3.2(\mathrm{SD} 0.3)$ & & $51 \cdot 7($ SD $1 \cdot 2)$ & & 68.5 (SD 9.5) & Yes \\
\hline \multirow[t]{6}{*}{ Prola et al. ${ }^{(31)}$} & Mix & FE & 4 & 6 & 5.6 & 3.6 & & 63.3 (SD 12.7) & & & $\begin{array}{l}\text { No - length of } \\
\text { study }\end{array}$ \\
\hline & Mix & FE & 4 & 6 & $5 \cdot 6$ & $3 \cdot 6$ & & $55.9(\mathrm{SD} 17.4)$ & & & $\begin{array}{l}\text { No - length of } \\
\text { study }\end{array}$ \\
\hline & Mix & $\mathrm{FE}$ & 4 & 6 & $5 \cdot 6$ & $3 \cdot 6$ & & $58.6(\mathrm{SD} 17.9)$ & & & $\begin{array}{l}\text { No - length of } \\
\text { study }\end{array}$ \\
\hline & Mix & FE & 4 & 6 & $5 \cdot 6$ & $3 \cdot 6$ & & $45.9($ SD 14.8$)$ & & & $\begin{array}{l}\text { No - length of } \\
\text { study }\end{array}$ \\
\hline & Mix & $\mathrm{FE}$ & 4 & 6 & $5 \cdot 6$ & $3 \cdot 6$ & & $45 \cdot 4($ SD $14 \cdot 3)$ & & & $\begin{array}{l}\text { No - length of } \\
\text { study }\end{array}$ \\
\hline & Mix & $\mathrm{FE}$ & 4 & 6 & $5 \cdot 6$ & $3 \cdot 6$ & & $26 \cdot 3($ SD $12 \cdot 0)$ & & & $\begin{array}{l}\text { No - length of } \\
\text { study }\end{array}$ \\
\hline \multirow[t]{5}{*}{ Radicke $^{(49)} \dagger$} & Mix & IC & & 14 & $4 \cdot 0$ & $4 \cdot 0$ & & 31.0 (SD 3.0) & & & Yes \\
\hline & Mix & IC & & 14 & 4.0 & 4.2 & & 37.0 (SD 5.5) & & & Yes \\
\hline & Mix & IC & & 14 & 4.0 & 3.9 & & $38.0($ SD 7.5$)$ & & & Yes \\
\hline & Mix & IC & & 14 & $4 \cdot 0$ & 3.9 & & 39.0 (SD 1.5) & & & Yes \\
\hline & Mix & IC & & 14 & 4.0 & 3.6 & & 39.0 (SD 7.0) & & & Yes \\
\hline \multirow[t]{2}{*}{ Riond et al. ${ }^{(33)} \ddagger$} & Mix & $\mathrm{FE}$ & 7 & 8 & & 4.4 & & $36 \cdot 4$ & & & $\begin{array}{l}\text { No - length of } \\
\text { study }\end{array}$ \\
\hline & Mix & FE & 7 & 8 & & 4.4 & & 31.5 & & & $\begin{array}{l}\text { No - length of } \\
\text { study }\end{array}$ \\
\hline Skultety ${ }^{(50)}$ & Mix & FE & & 32 & & 3.0 & & $74 \cdot 1$ & & & Yes \\
\hline
\end{tabular}


identified forty-two publications (Table 1) with data reporting the amount of energy required to maintain $\mathrm{BW}$ of adult cats. A 'publication' was defined as a distinct piece of published work, while 'treatment' represented a treatment group of cats within the publication (for example, a control or obese group).

Cats were classed according to sex and neuter status (entire male and female, neutered male and female). Due to an absence of body condition score or body composition assessment in the majority of publications, it was assumed that cat weight was an accurate estimate of whether the cat was lean, normal or overweight. Therefore, cats less than $3 \mathrm{~kg}$ in weight were classed as 'light', cats between 3.0 and $5.5 \mathrm{~kg}$ were classed as 'normal', and cats with BW greater than $5.5 \mathrm{~kg}$ were classed as 'heavy'. Thirteen publications reported maintenance energy requirements on a fat-free basis (Table 1). This smaller dataset (thirty-four treatment groups) was used to investigate the effects of age, neuter status and methodology on maintenance energy requirements, when expressed on the basis of fat-free (lean) body mass. Cats were also grouped according to age, with cats less than 2 years (but older than 6 months) classed as 'young'. Cats were classed as 'adult' between the ages of 2 and 7 years, and classed as 'senior' if they were older than 7 years of age.

In all cases, cats were domestic shorthaired from either private dwellings studied in a clinical setting, or from research colonies. For the purpose of the present review, energy requirements were synonymous with metabolisable energy (ME) intake (measured from feeding studies where BW was constant $(<10 \%$ change) over the feeding period), and total energy expenditure was assessed by doubly-labelled water (DLW). Additionally, resting energy expenditure as measured by indirect calorimetry (IC) was used as an estimate of energy requirements. Energy requirements for maintenance were therefore either classed as feeding experiments (FE), DLW or IC, and, where reported, the length of the study was also included (Table 1). Only data from FE that were more than $7 \mathrm{~d}$ were included in the present analysis.

The ME content of diets is determined by predictive equations using the 'Atwater factors' of 4.0, 9.0 and $4.0 \mathrm{kcal} / \mathrm{g}$ for protein, fat and carbohydrate, respectively ${ }^{(7)}$. These Atwater factors were modified in $1997^{(8)}$ to $3.5,8.5$ and $3.5 \mathrm{kcal} / \mathrm{g}$ for protein, fat and carbohydrate, respectively. Therefore, in order to compare energy intake in the FE studies pre- and post- the Atwater modifications, the energy intakes reported in the studies published before and including 1997 ( $n$ 7; Table 1) were recalculated using the modified Atwater equations unless: (1) the energy content of the diet was measured by bomb calorimeter or (2) the publication stated that modified Atwater equations were used to determine the energy content of the diet.

\section{Statistical analysis}

Energy requirements are provided as $\mathrm{kcal} / \mathrm{kg}$, rather than as $\mathrm{kJ} / \mathrm{kg}$, since the former units are used by the NRC for companion animals.

The initial dataset consisted of forty-two publications, representing 141 treatment groups of cats. Problems associated with fluctuating BW over the experimental period or missing data on BW led to twenty-six treatment groups being removed (Table 1). The revised dataset of 115 treatment 
groups was used for further analysis, and tested for normality and the presence of outliers. The dataset was found to be within normal statistical limits, and all 115 treatment groups were included in the meta-analysis.

A general linear model $\left(\right.$ Minitab $^{\circledR}$ statistical software, version 15, 2006; Minitab Inc., State College, PA, USA) was used to predict average energy requirements and determine the influence of factors such as age, sex and neuter status and methodology used to determine energy requirements. The allometric equation of $\mathrm{Y}=\mathrm{aBW}^{\mathrm{b}}$ was used to determine the relationship between $\mathrm{BW}$ and $\mathrm{ME}$ requirements, where $\mathrm{Y}$ is the dependent variable (ME requirement; $\mathrm{kcal}$ ), $\mathrm{a}$ is the constant coefficient, BW is body weight $(\mathrm{kg})$ and $\mathrm{b}$ is the allometric exponent ${ }^{(9)}$. Additionally, a regression model was used to determine the allometric relationship between $\mathrm{BW}$ and energy intake by performing a regression of the logarithms of energy intake $(\mathrm{kcal} / \mathrm{d})$ and $\mathrm{BW}(\mathrm{kg})^{(9)}$. In order to report data on a ' $\mathrm{kcal} / \mathrm{kg} \mathrm{BW}$ ' basis, the log data generated by Minitab were back-transformed using the inverse of logbase10. Results, unless otherwise stated, are reported as mean and standard error of the mean.

\section{Results and discussion}

The literature review identified forty-two publications, detailing energy requirements on the basis of BW from 141 treatment groups containing 1933 cats. Some publications did not report BW of the cats used ${ }^{(10-15)}$ (twenty-six treatment groups), but of those that did, cats identified as having a normal weight predominated with seventy-nine treatment groups. Light (nineteen treatment groups) and heavy cats (seventeen treatment groups) had similar numbers of treatment groups (Table 2). Only $57 \%$ of the treatment groups identified the age of the cats used in their study, with young cats (thirtyfour treatment groups) and adult cats (twenty-seven treatment groups) most studied (Table 2). The energy requirement of neutered cats was reported more frequently than those of entire cats (thirty-four $v$. twenty-six treatment groups, respectively). Feeding studies were the most common method of investigating energy requirements for maintenance of BW (fifty-nine treatment groups), followed by IC (thirtyeight treatment groups), and finally DLW techniques (eighteen treatment groups; see Table 2).

Average energy intake required for the maintenance of BW was $222 \cdot 1$ (SE 5.3) kcal/d, or $55 \cdot 6$ (SE 1.1) kcal $/ \mathrm{kg} \mathrm{BW}$ (115 treatment groups; Table 2). Overall, maintenance energy requirements were significantly affected by weight, sex and neuter status, age and methodology $(P<0 \cdot 05)$. As indicated in Table 2, there were large amounts of variation in the reported maintenance energy data, ranging from 122.5 to $401 \cdot 0 \mathrm{kcal} / \mathrm{d}$, which equated to $29 \cdot 0-85 \cdot 5 \mathrm{kcal} / \mathrm{kg} \mathrm{BW}$. The large amount of variation observed among studies has previously been attributed to the use of unmodified Atwater factors ${ }^{(5)}$. However, the present dataset was adjusted for differences in Atwater factors, making it likely that other factors, such as sex/neuter status of the cat or age were the cause of the variation in the reported data.

The allometric equation for maintenance energy requirements in all cats was calculated with a back-transformed equation of $77.6 \mathrm{kcal} / \mathrm{kg} \mathrm{BW} \mathrm{BW}^{-0.711}$ (Table 3 ; adjusted $R^{2}$ $0.448 ; 115$ treatment groups).

\section{Effects of body weight}

BW ranged from 2.6 to $6.6 \mathrm{~kg}$ (Table 2), and averaged 2.8 (SE 0.02 ) $\mathrm{kg}$ in light cats (nineteen treatment groups), 4.0 (SE 0.07$) \mathrm{kg}$ in normal cats (seventy-nine treatment groups) and 6.0 (SE 0.07) $\mathrm{kg}$ in the heavy cats (seventeen treatment groups) (Table 2). When expressed as a proportion of $\mathrm{BW}$, the energy requirements of light cats $(62.8$ (SE 2.8) $\mathrm{kcal} / \mathrm{kg}$ $\mathrm{BW}$; nineteen treatment groups) were greater compared with both normal (56.3 (SE 1.2) $\mathrm{kcal} / \mathrm{kg} \mathrm{BW}$; seventy-nine treatment groups) and heavy cats (43.9 (SE 1.7) $\mathrm{kcal} / \mathrm{kg} \mathrm{BW}$; $P<0.05$; seventeen treatment groups). Heavy cats have a lower maintenance energy requirement than normal and light cats $(P<0 \cdot 01$; Table 2$)$.

Table 2. Maintenance energy intakes and body weight (BW) for domestic cats (Mean values, standard errors and ranges)

\begin{tabular}{|c|c|c|c|c|c|c|c|c|c|c|}
\hline & \multirow[b]{2}{*}{$n$} & \multicolumn{3}{|c|}{ ME intake (kcal/d) } & \multicolumn{3}{|c|}{ BW (kg) } & \multicolumn{3}{|c|}{ ME intake (kcal/kg BW) } \\
\hline & & Mean & SE & Range & Mean & SE & Range & Mean & SE & Range \\
\hline All cats & 115 & $222 \cdot 1$ & $5 \cdot 3$ & $122 \cdot 5-401 \cdot 0$ & $4 \cdot 1$ & $0 \cdot 1$ & $2 \cdot 6-6 \cdot 6$ & $55 \cdot 6$ & $1 \cdot 1$ & $29 \cdot 0-85.5$ \\
\hline Light-weight cats (<3 kg) & 19 & $178 \cdot 8$ & $8 \cdot 1$ & $123 \cdot 2-250 \cdot 5$ & $2 \cdot 8$ & $0 \cdot 1$ & $2 \cdot 6-2.9$ & $62 \cdot 8$ & $2 \cdot 8$ & $44.5-85.5$ \\
\hline Normal-weight cats $(3.0-5.5 \mathrm{~kg})$ & 79 & $224 \cdot 1$ & $6 \cdot 5$ & $122 \cdot 5-401 \cdot 0$ & 4.0 & $0 \cdot 1$ & $3 \cdot 0-5 \cdot 3$ & $56 \cdot 3$ & $1 \cdot 2$ & $31 \cdot 0-79 \cdot 0$ \\
\hline Heavy-weight cats $(>5.5 \mathrm{~kg})$ & 17 & $262 \cdot 1$ & $9 \cdot 3$ & $174 \cdot 0-342 \cdot 0$ & $6 \cdot 1$ & $0 \cdot 1$ & $5 \cdot 5-6 \cdot 6$ & 43.9 & 1.7 & $29 \cdot 0-60 \cdot 0$ \\
\hline Entire female & 12 & $215 \cdot 0$ & $12 \cdot 4$ & $137 \cdot 3-282 \cdot 1$ & $3 \cdot 3$ & 0.2 & $2 \cdot 6-4.5$ & $66 \cdot 0$ & 2.5 & $52 \cdot 8-85 \cdot 5$ \\
\hline Entire male & 12 & $280 \cdot 3$ & $18 \cdot 3$ & $171 \cdot 5-401 \cdot 0$ & $4 \cdot 7$ & $0 \cdot 2$ & $3 \cdot 5-5 \cdot 8$ & $60 \cdot 9$ & $3 \cdot 2$ & $48 \cdot 9-78 \cdot 6$ \\
\hline Neutered female & 20 & $192 \cdot 6$ & 8.7 & $123 \cdot 2-257 \cdot 4$ & $3 \cdot 3$ & $0 \cdot 1$ & $2 \cdot 7-4.5$ & $58 \cdot 2$ & $2 \cdot 4$ & $44.5-84.4$ \\
\hline Neutered male & 14 & 243.7 & $16 \cdot 9$ & $134 \cdot 9-379 \cdot 2$ & 4.5 & 0.2 & $3 \cdot 3-6 \cdot 0$ & $55 \cdot 2$ & $3 \cdot 2$ & $39 \cdot 0-79 \cdot 0$ \\
\hline Mix & 57 & $216 \cdot 3$ & $7 \cdot 0$ & $122 \cdot 5-342 \cdot 0$ & 4.4 & 0.2 & $2 \cdot 8-6 \cdot 6$ & 51.4 & 1.4 & $29 \cdot 0-76 \cdot 4$ \\
\hline Young $(0.5-2.0$ years $)$ & 34 & $228 \cdot 0$ & $10 \cdot 7$ & $123 \cdot 2-379 \cdot 2$ & 3.9 & 0.2 & $2 \cdot 6-6 \cdot 1$ & 59.4 & $2 \cdot 1$ & $40 \cdot 9-85 \cdot 5$ \\
\hline Adult (2.0-7.0 years) & 27 & $199 \cdot 1$ & $9 \cdot 9$ & $122 \cdot 3-316 \cdot 2$ & $4 \cdot 2$ & 0.2 & $2 \cdot 8-6 \cdot 6$ & $48 \cdot 4$ & 1.8 & $31 \cdot 0-65 \cdot 4$ \\
\hline Senior ( $>7.0$ years) & 7 & $194 \cdot 2$ & $18 \cdot 6$ & $135 \cdot 0-379 \cdot 2$ & 3.9 & 0.2 & $3 \cdot 2-4.5$ & $51 \cdot 1$ & $3 \cdot 2$ & $39 \cdot 0-63 \cdot 1$ \\
\hline Unknown & 47 & $235 \cdot 2$ & $7 \cdot 6$ & $141 \cdot 4-401 \cdot 0$ & $4 \cdot 2$ & 0.2 & $2 \cdot 8-6 \cdot 3$ & $57 \cdot 6$ & 1.6 & $29 \cdot 0-78 \cdot 6$ \\
\hline Feeding experiments & 59 & $230 \cdot 2$ & $6 \cdot 9$ & $123 \cdot 2-401 \cdot 0$ & 4.2 & 0.2 & $2 \cdot 8-6 \cdot 6$ & $58 \cdot 0$ & 1.6 & $35 \cdot 8-85.5$ \\
\hline Indirect calorimetry & 38 & $203 \cdot 7$ & $8 \cdot 2$ & $122 \cdot 5-305 \cdot 0$ & $4 \cdot 1$ & 0.2 & $2 \cdot 8-6 \cdot 2$ & $50 \cdot 0$ & 1.5 & $29 \cdot 0-70 \cdot 0$ \\
\hline Doubly-labelled water & 18 & $234 \cdot 2$ & $17 \cdot 0$ & $134.9-379 \cdot 2$ & 3.9 & 0.2 & $2 \cdot 6-4 \cdot 8$ & $59 \cdot 2$ & $2 \cdot 4$ & $40 \cdot 9-79 \cdot 0$ \\
\hline
\end{tabular}

$\mathrm{ME}$, metabolisable energy; $n$, number of treatment groups. 
Table 3. Allometric regression equations $\left(Y=a B W^{b}\right)$ for maintenance requirements for cats based on the log-log regression of metabolisable energy (ME) intake (kcal/d) and body weight $(\mathrm{kg})$

\begin{tabular}{lccccc}
\hline & $n$ & Constant coefficient (a) & kcal equivalent* & Log BW (b) & Adjusted $R^{2}(\%)$ \\
\hline All cats & 115 & 1.89 & 77.6 & 0.711 & 0.448 \\
Light-weight cats $(<3 \mathrm{~kg})$ & 19 & 1.73 & 53.7 & 1.061 & 0.000 \\
Normal-weight cats $(3 \cdot 0-5.5 \mathrm{~kg})$ & 79 & 1.67 & 46.8 & 1.115 & 0.425 \\
Heavy-weight cats $(>5.5 \mathrm{~kg})$ & 17 & 2.12 & 131.8 & 0.366 & 0.000 \\
Normal- and light-weight cats $(<3-5.5 \mathrm{~kg})$ & 98 & 1.76 & 56.2 & 0.966 & 0.479 \\
Entire female & 12 & 1.69 & 49.0 & 1.193 & 0.736 \\
Entire male & 12 & 1.85 & 70.8 & 0.882 & 0.213 \\
Neutered female & 20 & 1.73 & 53.7 & 1.023 & 0.378 \\
Neutered male & 14 & 1.89 & 77.6 & 0.754 & 0.189 \\
Young (0.5-2.0 years) & 34 & 1.82 & 72.4 & 0.878 & 0.596 \\
Adult (2.0-7.0 years) & 27 & 1.86 & 67.6 & 0.703 & 0.457 \\
Senior $(>7.0$ years) & 7 & 1.83 & 87.1 & 0.781 & 0.173 \\
Feeding experiments & 59 & 1.94 & 77.6 & 0.656 & 0.466 \\
Indirect calorimetry & 38 & 1.89 & 44.7 & 1.195 & 0.405 \\
Doubly-labelled water & 18 & 1.65 & & 0.684 \\
\hline
\end{tabular}

$\mathrm{Y}$, energy requirement; a, allometric coefficient; BW, body weight; $\mathrm{b}$, allometric exponent; $n$, number of treatment groups.

${ }^{*}$ Back-transformed using the inverse of log-base10.

The effects of $\mathrm{BW}$ on the allometric equations are indicated in Table 3. When both light- and normal-weight cats were incorporated into the same group to allow direct comparison with the normal and light equation identified by the $\mathrm{NRC}^{(5)}$, the allometric equation was $56 \cdot 2 \mathrm{kcal} / \mathrm{kg} \mathrm{BW}^{-0.966}$ (adjusted $R^{2} 0.479$; ninety-eight treatment groups). This value is lower than the NRC recommendations for light and normal cats $\left(100 \mathrm{kcal} / \mathrm{BW}^{-067}\right)$. Both the predicted allometric equations for light- and heavy-weight cats have an adjusted $R^{2}$ of 0.000 . This may be due to the low number of treatment groups, but more likely the high variation among cats at these $\mathrm{BW}$. This suggests that more data are required in these classes of cats.

Figure 1 shows the actual data reported for domestic cats ( $\mathrm{kcal} / \mathrm{d})$ compared with the predicted energy requirements using the allometric equations for light and normal cats and

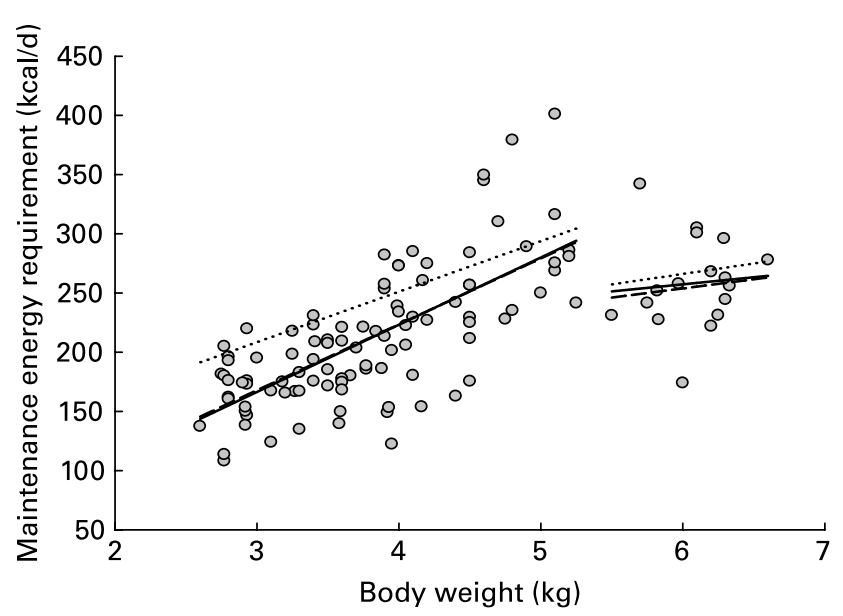

Fig. 1. Effect of body weight (BW) on the maintenance energy requirements in domestic cats $(\mathrm{O} ;-)$, compared with the predicted requirements from the present study $(---)$ and those predicted by the National Research Council $^{(5)}(. . . .$.$) . Allometric equations predicted from the present study were$ $56.2 \mathrm{kcal} / \mathrm{kg} \mathrm{BW}^{-0.966}$ and $131.8 \mathrm{kcal} / \mathrm{kg} \mathrm{BW}^{-0.366}$ for light and normal cats and heavy cats, respectively, in the present study. The corresponding predictive equations from the National Research Council(5) were $100 \mathrm{kcal} / \mathrm{kg}$ $\mathrm{BW}^{-0.667}$ and $130 \mathrm{kcal} / \mathrm{kg} \mathrm{BW}^{-0.40}$ for light and normal cats and heavy cats, respectively. heavy cats from the present study and those of the NRC for light and normal cats and heavy cats. The prediction of energy requirements for maintenance of BW from the present study for light and normal cats and heavy cats is consistent with the actual ME requirements reported in the literature (Fig. 1) and suggests that the current $\mathrm{NRC}^{(5)}$ recommendations over-predict the energy requirements for light- and normal-weight domestic cats. Over time this additional ME intake could lead to weight gain that may exacerbate specific orthopaedic, endocrine, cardiovascular and neoplastic diseases associated with obesity ${ }^{(16)}$. However, when using predicted allometric equations either from the present study or those by the NRC, care should be taken to feed an individual cat to its specific requirements based on body condition and exercise levels due to the individual variation that exists among cats.

The amount of variation explained in both the overall, normal and combined light and normal cat groups was low, with an adjusted $R^{2}<0.479$, which prompted the investigation of factors that may have influenced the results. These factors included sex and neuter status, and methodology used to determine maintenance energy requirements.

The $\mathrm{NRC}^{(5)}$ highlighted that cats classed as 'normal' may indeed be overweight and that energy requirements for maintenance would be better expressed on the basis of fat-free mass. On average, lean body mass was $3 \cdot 2$ (SE $0 \cdot 1) \mathrm{kg}$, ranging from 2.0 to $4.2 \mathrm{~kg}$ (Table 4). Mean maintenance energy requirements, when expressed on the basis of fat-free (lean) mass, were 68.6 (SE 1.9) kcal/kg lean mass, ranging from 42.8 to $90.3 \mathrm{kcal} / \mathrm{kg}$ lean mass (thirty-nine treatment groups). The allometric equation generated for this dataset equated to $58.4 \mathrm{kcal} / \mathrm{kg}$ lean mass ${ }^{-1.140}$ (adjusted $R^{2} 0.690$; thirty-four treatment groups). The amount of variation explained by this model was nearly twice that of the allometric equations generated from BW data.

\section{Age effects}

Data showing maintenance energy requirements according to age are presented in Table 2. Forty-seven treatment groups did not have any information on the age of the cats so data 
Table 4. Mean maintenance energy intakes for domestic cats based on fat-free (lean) mass (Mean values, standard errors and ranges)

\begin{tabular}{|c|c|c|c|c|c|c|c|c|c|c|}
\hline & \multirow[b]{2}{*}{$n$} & \multicolumn{3}{|c|}{ ME intake (kcal/d) } & \multicolumn{3}{|c|}{ Fat-free mass (kg) } & \multicolumn{3}{|c|}{$\begin{array}{c}\text { ME intake } \\
(\mathrm{kcal} / \mathrm{kg} \text { fat-free mass })\end{array}$} \\
\hline & & Mean & SE & Range & Mean & SE & Range & Mean & SE & Range \\
\hline All cats & 38 & $223 \cdot 1$ & $10 \cdot 9$ & $104 \cdot 5-379 \cdot 2$ & $3 \cdot 2$ & 0.1 & $2 \cdot 0-4 \cdot 2$ & $68 \cdot 6$ & 1.9 & $42 \cdot 8-90 \cdot 3$ \\
\hline Light-weight cats $(<3 \mathrm{~kg})$ & 7 & 143.5 & $12 \cdot 9$ & $104 \cdot 5-192 \cdot 7$ & $2 \cdot 1$ & 0.1 & $2 \cdot 0-2 \cdot 2$ & $67 \cdot 7$ & $5 \cdot 6$ & $52 \cdot 1-90 \cdot 3$ \\
\hline Normal-weight cats $(3.0-5.5 \mathrm{~kg})$ & 26 & 233.9 & $12 \cdot 1$ & $134.9-379 \cdot 2$ & 3.4 & 0.1 & $2.4-4.2$ & $67 \cdot 7$ & $2 \cdot 2$ & $42 \cdot 8-90 \cdot 3$ \\
\hline Heavy-weight cats $(>5.5 \mathrm{~kg})$ & 5 & 278.9 & $9 \cdot 8$ & $260 \cdot 5-305 \cdot 0$ & 3.7 & 0.1 & $3 \cdot 6-3 \cdot 9$ & $75 \cdot 2$ & 3.5 & $68 \cdot 6-84 \cdot 1$ \\
\hline Entire female & 3 & $188 \cdot 3$ & 33.6 & $137 \cdot 3-251 \cdot 6$ & 2.5 & 0.3 & $2 \cdot 1-3 \cdot 1$ & $75 \cdot 0$ & $5 \cdot 1$ & $64 \cdot 8-80 \cdot 3$ \\
\hline Entire male & 6 & 273.9 & $29 \cdot 8$ & $171.5-349.6$ & $3 \cdot 6$ & 0.3 & $2 \cdot 8-4 \cdot 2$ & $74 \cdot 6$ & 3.5 & $61 \cdot 9-85 \cdot 3$ \\
\hline Neutered female & 8 & 187.9 & $9 \cdot 0$ & $162 \cdot 0-229 \cdot 3$ & $2 \cdot 6$ & 0.1 & $2 \cdot 1-3 \cdot 0$ & $71 \cdot 2$ & 3.9 & $56 \cdot 0-90 \cdot 3$ \\
\hline Neutered male & 7 & 230.5 & $30 \cdot 3$ & $134.9-379.2$ & 3.6 & 0.3 & $2 \cdot 6-4 \cdot 2$ & $64 \cdot 6$ & $6 \cdot 2$ & $42 \cdot 8-90 \cdot 3$ \\
\hline Mix & 14 & $225 \cdot 3$ & $18 \cdot 4$ & $104 \cdot 5-305 \cdot 0$ & $3 \cdot 2$ & 0.2 & $2.0-3.9$ & 65.5 & $2 \cdot 7$ & $52 \cdot 1-84 \cdot 1$ \\
\hline \multicolumn{11}{|l|}{ Young $(0.5-2.0 \text { years })^{*}$} \\
\hline Adult ( $2 \cdot 0-7 \cdot 0$ years) & 22 & 218.9 & 14.4 & $104 \cdot 5-379 \cdot 2$ & $3 \cdot 0$ & 0.2 & $2 \cdot 0-4 \cdot 2$ & $69 \cdot 5$ & $2 \cdot 2$ & $52 \cdot 1-90 \cdot 3$ \\
\hline Senior ( $>7.0$ years) & 7 & $200 \cdot 3$ & $16 \cdot 5$ & $167 \cdot 1-286 \cdot 3$ & $3 \cdot 4$ & 0.3 & $2 \cdot 4-4 \cdot 1$ & $60 \cdot 2$ & $4 \cdot 3$ & $42 \cdot 8-73 \cdot 8$ \\
\hline Unknown & 5 & 276.8 & $10 \cdot 9$ & $250 \cdot 0-305 \cdot 0$ & 3.7 & 0.1 & $3.5-3.9$ & $76 \cdot 0$ & 3.2 & $68 \cdot 6-84 \cdot 1$ \\
\hline Feeding experiments & 6 & 214.6 & $22 \cdot 3$ & $168 \cdot 8-300 \cdot 2$ & 3.6 & 0.2 & $3 \cdot 0-4 \cdot 1$ & $60 \cdot 7$ & $6 \cdot 0$ & $42 \cdot 8-84 \cdot 1$ \\
\hline Indirect calorimetry & 15 & $218 \cdot 2$ & $17 \cdot 0$ & $104 \cdot 5-305 \cdot 0$ & 3.0 & 0.2 & $2 \cdot 0-4 \cdot 1$ & 65.4 & $2 \cdot 2$ & $52 \cdot 1-83 \cdot 3$ \\
\hline Doubly-labelled water & 17 & 230.5 & $18 \cdot 2$ & $134.9-379.2$ & $3 \cdot 1$ & 0.2 & $2 \cdot 1-4 \cdot 2$ & 74.0 & 2.6 & $52 \cdot 8-90 \cdot 3$ \\
\hline
\end{tabular}

ME, metabolisable energy; $n$, number of treatment groups.

${ }^{*}$ No data were reported in young cats ( $>2$ years) on the basis of fat-free mass.

from the remaining sixty-eight groups were used to determine maintenance energy requirements (Table 1). Despite this, age was seen to have a significant effect on the daily energy required for maintenance $(P<0.05$; Table 2$)$. When expressed as a proportion of $\mathrm{BW}$, daily energy requirements were higher $(P<0.05)$ in young cats $(59.4($ SE $2 \cdot 1) \mathrm{kcal} / \mathrm{kg} \mathrm{BW}$; thirty-four treatment groups), compared with adult cats (48.4 (SE 1.8) $\mathrm{kcal} / \mathrm{kg} \mathrm{BW}$; twenty-seven treatment groups). However, senior cats $(48.4(\mathrm{SE} 4.2) \mathrm{kcal} / \mathrm{kg} \mathrm{BW}$; seven treatment groups) had similar energy requirements to both young and adult cats $(P>0.05)$.

Back-transformed allometric equations identified that young cats had daily maintenance energy requirements of $66.1 \mathrm{kcal} /$ $\mathrm{BW}^{-0.878}$, while adult cats needed $72.4 \mathrm{kcal} / \mathrm{BW}^{-0703}$ and senior cats $67.6 \mathrm{kcal} / \mathrm{BW}^{-0.781}$ (Table 3). The allometric equations determined in the present study for young cats (Table 3) imply that young cats have higher energy requirements than older cats. For young cats, the regression model explained $59.6 \%$ of the variation of the data; however, less variation was explained in adult (adjusted $R^{2} 0.457$ ) and senior (adjusted $R^{2} 0.173$ ) groups. Kienzle et al. ${ }^{(17)}$ suggested that low exponentials of BW may be due to higher incidences of overweight cats in the population.

When expressed on the basis of fat-free mass, age had a significant influence on maintenance energy requirements $(P<0.05$; Table 4). However, on analysis of the data there was no difference $(P>0.05)$ between adult (69.5 (SE 2.2) $\mathrm{kcal} / \mathrm{kg}$ lean mass per $\mathrm{d}$; twenty-seven treatment groups) and senior cats $(60.2$ (SE 4.3) kcal/kg lean mass per d; seven treatment groups), with cats of unknown age status having the highest energy requirements $(75.9$ (SE 3.2) kcal/kg lean mass per d; five treatment groups).

Published data on the effects of age on energy requirements are extremely variable. Burger ${ }^{(1)}$, Harper et al. ${ }^{(18)}$, and Peachey et al. ${ }^{(19)}$ have all shown that energy requirement does not change with age. Similarly, Taylor et al. ${ }^{(15)}$ found no effect of age on ME intake in cats up to 10 years old.
However, 12- to 14-year-old cats have been reported as having significantly higher daily energy requirements ${ }^{(15)}$. A retrospective analysis of colony cats showed that daily energy requirements decreased from $74 \mathrm{kcal} / \mathrm{kg} \mathrm{BW}$ in young adult cats $(>2-6$ years of age) to $51 \mathrm{kcal} / \mathrm{kg} \mathrm{BW}$ in older adults $(7-15 \text { years of age })^{(2)}$. Similarly, Kienzle et al. ${ }^{(17)}$ suggested that the daily requirements of cats over 6 years did not change, averaging $130 \mathrm{kcal} / \mathrm{kg} \mathrm{BW}^{-0.40}$ (equivalent to $67 \mathrm{kcal} / \mathrm{kg} \mathrm{BW}$ in a $3 \mathrm{~kg}$ cat). Nguyen et al. ${ }^{(20)}$ observed an age effect on energy requirements in castrated male cats. Scarlett et al. ${ }^{(21)}$ suggested that age effects may be masked by weight effects, as older cats tend to be less overweight than adult and younger cats.

\section{Sex and neuter effects}

Neuter status significantly affected daily maintenance energy requirements in cats (Tables 2 and $4 ; \quad P<0 \cdot 001$ ). When expressed as energy intake per $\mathrm{d}$, reproductively entire male cats $(280.3(\mathrm{SE} 18.3) \mathrm{kcal} / \mathrm{d}$; twelve treatment groups) tended to have higher $(P<0 \cdot 10)$ energy requirements than reproductively entire female cats $(215.0$ (SE 12.4) kcal/d; twelve treatment groups). However, when expressed as a proportion of BW this effect was not apparent. This trend was observed in neutered male $(55 \cdot 2$ (SE 3.2) kcal/kg BW; fourteen treatment groups) and female cats $(58.2$ (SE 2.4) kcal/kg BW; twenty treatment groups). Overall, neutered cats (56.6 (SE 2.0) $\mathrm{kcal} / \mathrm{kg} \mathrm{BW}$; thirty-four treatment groups) required $10.4 \%$ less energy than their reproductively entire counterparts (63.2 (SE 2.2) kcal/kg BW; twenty-four treatment groups; $P<0 \cdot 05)$.

When expressed on the basis of fat-free mass ( $\mathrm{kcal} / \mathrm{kg}$ fatfree mass), sex had no influence $(P>0.05)$ on maintenance energy requirements (Table 4).

As previously observed for age, the effects of neutering on energy requirements also differed among studies. Kanchuk et al. ${ }^{(22)}$ found that neutering increased daily energy 
expenditure, while Flynn et al. ${ }^{(23)}$, Martin et al. ${ }^{(24)}$ and Nguyen et al. ${ }^{(20)}$ all observed a decrease in energy expenditure and ME intake, in neutered animals. In contrast, both Fettman et al. ${ }^{(25)}$ and Nguyen et al. ${ }^{(26)}$ showed no difference in RMR and energy expenditure after neutering. Harper et al. ${ }^{(18)}$ observed that the average daily energy requirement for maintaining $\mathrm{BW}$ in neutered females was $45 \mathrm{kcal} / \mathrm{kg} \mathrm{BW}$. Differences between male and female cats in their response to neutering may also exist. Hoenig \& Ferguson ${ }^{(27)}$ observed no effect of neutering on male cats; however, there was a significant reduction in daily energy requirements in female cats post-neutering. Additionally, Fettman et al. ${ }^{(25)}$ showed that, while there were no differences due to neutering, neutered females had higher RMR than neutered males.

\section{Methodology effects}

Table 2 indicates the average values for the different methods of determining maintenance energy requirements. The method used to determine maintenance energy requirements had no effect on daily energy requirement; however, there was a significant effect $(P<0 \cdot 01)$ on energy requirements when expressed as a proportion of BW. IC (50.0 (SE 1.5) kcal/kg $\mathrm{BW} / \mathrm{d}$; thirty-eight treatment groups) gave slightly lower values than FE methodology (58.6 (SE 1.6) $\mathrm{kcal} / \mathrm{kg} \mathrm{BW} / \mathrm{d}$; fifty-nine treatment groups; $P<0.05)$ and DLW $(59.2$ (SE 2.4 ) $\mathrm{kcal} / \mathrm{kg} \mathrm{BW} / \mathrm{d}$; eighteen treatment groups; $P<0 \cdot 10$ ). However, as it is likely that cats measured using IC would be less active (i.e. in calorimetric chambers), this is not surprising. The allometric equations reported in Table 3 differed slightly from those reported by Nguyen et al. ${ }^{(28)}$ for $\mathrm{FE}\left(150 \mathrm{kcal} \times \mathrm{BW}^{-040}\right)$, DLW $\left(83 \mathrm{kcal} \times \mathrm{BW}^{-089}\right)$ and IC $\left(54 \mathrm{kcal} \times \mathrm{BW}^{-0.65}\right)$.

When expressed on the basis of fat-free mass, methodology influenced maintenance energy requirements (Table 4), with DLW (73.9 (SE 2.6) kcal/kg lean mass per d; seventeen treatment groups) values higher $(P<0 \cdot 10)$ than both IC (65.4 (SE 2.2) kcal/kg lean mass per d; fifteen treatment groups) and FE (60.7 (SE 6.0) kcal/kg lean mass per d; six treatment groups).

\section{Points for reflection}

Maintenance energy requirements for domestic cats in the present study were determined by a retrospective analysis of the data in the literature, and were affected by factors such as BW, age and the sex of the cat. The equations for normal and light cats $\left(56.2 \mathrm{kcal} / \mathrm{kg} \mathrm{BW} \mathrm{BW}^{-0.966}\right)$ and heavy cats $\left(131.8 \mathrm{kcal} / \mathrm{kg} \mathrm{BW}^{-0.366}\right)$ in the present study were lower than those reported by the $\mathrm{NRC}^{(5)}$. We recommend that three allometric equations should ideally be used when predicting the energy requirements for the maintenance of $\mathrm{BW}$ in the cat, namely light $(53.7 \mathrm{kcal} / \mathrm{kg} \mathrm{BW}-1.061)$, normal $\left(46 \cdot 8 \mathrm{kcal} / \mathrm{kg} \mathrm{BW}^{-1 \cdot 115}\right)$ and heavy $\left(131.8 \mathrm{kcal} / \mathrm{kg} \mathrm{BW}^{-0.366}\right)$. However, the large variation among treatment groups may partly explain the relatively low relationships (as indicated by $R^{2}$ ) between BW and ME requirements. Therefore, care must be taken when applying these equations to individual animals. Ideally, allometric equations based on body condition score would be more informative than those based on BW. However, with the present dataset there are not enough publications reporting body condition scores and corresponding energy requirements for these to be determined. Authors and reviewers of future publications could look at including a more detailed set of background data in their publications so that these equations can be determined.

The use of lean mass to assess the maintenance energy requirements for domestic cats seemed to be less influenced by factors such as the weight and sex of the animal. While age had an effect on the maintenance energy requirements when expressed on the basis of lean mass, this may be a function of the lack of information in most of the age groups. A limitation of the present study is the assumption that normal cats weigh between 3.0 and $5.5 \mathrm{~kg}$ and cats with BW greater than $5.5 \mathrm{~kg}$ are heavy. It appears from the present study that lean body mass is the best predictor of maintenance energy requirements. If this is the case, there is a need to report background details concerning the body composition of the cats studied in such trials, so that a more accurate prediction of $\mathrm{ME}$ requirements can be made. Determining lean body mass is expensive and may not always be practical for determining the $\mathrm{ME}$ requirements for a particular cat population. Therefore the use of other tools (for example, The Feline Body Mass Index ${ }^{\mathrm{TM}}$ ) or using body condition score to assess leanness may be more practical.

For the purpose of the present review, it was assumed that physical activity of cats in colony settings would be relatively low, and resting energy expenditure as measured by IC was used as an accurate estimate of ME requirements. Unpublished results at the Waltham Centre of Pet Nutrition supported this claim. However, from the results of our analysis there was an effect of the methodology used when energy requirements were expressed as a proportion of BW, suggesting that the physical activity of colony cats may be higher than originally suspected.

In the literature, there were little data from older cats, especially those greater than 14 years of age. Similarly, 120 out of 123 treatment groups were colony cats (Table 1), with only the remaining three groups being pet cats. Colony cats included those in normal colony populations ${ }^{(15,19)}$, or those used to elucidate a wide range of dietary effects ${ }^{(28-31)}$. Pet cats were adult cats sourced from private households and monitored in the laboratory ${ }^{(32,33)}$. There are no published reports describing the energy expenditure of cats within a domestic home environment. It is likely that cats in the home environment may have even higher energy requirements than their colony counterparts, as they have the freedom to roam, and may require higher energy intake to maintain BW. Finally, all studies were carried out in laboratory environments, thus excluding any possible effects of environmental temperature fluctuation on energy requirements. This forms an important area of investigation for the future. A recent review by Hill $^{(34)}$ highlighted problems trying to extrapolate energy requirement data from healthy colony animals to pets at home which may have more or less exercise, be kept in a warmer or more controlled environment, are more likely to be overweight, and/or are a different breed to the standard colony cat.

\section{Conclusions}

The ME requirements reported in the present study were lower than those reported by the NRC, and this may have a 
significant impact on the feeding levels of cats and longerterm issues with obesity and related diseases. However, there was large variation among cats in the energy requirements for maintenance. Therefore care must be taken when devising the ME requirements for an individual cat, and other measures such as body condition score should be used to determine a more accurate ME requirement. Finally, the review highlighted the lack of data at the 'extreme' ends of the spectrum, namely, the lightest and oldest cats and those maintained in outdoor environments. The amount of variation in cat populations, and the scarcity of information available for young, senior and entire cats may mask any true differences in the energy requirements for maintenance of $\mathrm{BW}$.

\section{Acknowledgements}

The present study received no specific grant from any funding agency in the public, commercial or not-for-profit sectors.

The statistical advice and discussions with John Koolaard (AgResearch Ltd, New Zealand) are gratefully appreciated. The authors acknowledge the insightful conversations with Dr Richard Hill (University of Florida, USA).

The literature review, meta-analysis and writing were conducted by E. N. B. at the Waltham Centre for Pet Nutrition. D. G. T., P. J. M and A. J. H. all contributed equally to data evaluation and writing of the manuscript.

The authors state that there is no conflict of interest.

\section{References}

1. Burger IH (1994) Energy needs of companion animals: matching food intakes to requirements throughout the life cycle. J Nutr 124, 2584S-S2593S.

2. Pérez-Comago G (2004) Cat nutrition: what is new in the old. Compend Cont Educ Pract Vet 26, 5-10.

3. Earle KE \& Smith PM (1991) Digestible energy requirements of adult cats at maintenance. $J$ Nutr 121, S45-S46.

4. Phillips CJ (2005) Meta-analysis - a systematic and quantitative review of animal experiments to maximise the information derived. Anim Welf 14, 333-338.

5. National Research Council (2006) Energy. In Nutrient Requirements of Dogs and Cats, pp. 28-48. Washington, DC: National Academies Press.

6. Bermingham EN, Morris P \& Hawthorne AJ (2007) Energy requirements in cats; a meta-analysis. In Proceedings of the 11th European Society of Veterinary and Comparative Nutrition, Leipzig, Germany, 1-3 November 2007 Leipzig, Germany: Merkur Druck- und Kopierzentrum GmbH.

7. Kienzle E (2002) Further developments in the prediction of metabolisable energy (ME) in pet food. $J$ Nutr 132, 1796S-1798S.

8. Anonymous (2009) Model bill and regulations. In Association of American Feed Control Officials Official Publication, Chapter 3, pp. 94-189. Atlanta, GA: AAFCO.

9. Earle KE \& Smith PM (1991) Digestible energy requirements of adult cats at maintenance. $J$ Nutr 121, 45S-46S.

10. Caldwell GT (1931) Studies in water metabolism of the cat. Physiol Zool 4, 324-355.

11. Edtstadtler-Pietsch G (2003) Untersuchugen zum Energiebedarf von Katzen (Investigations on energy requirements of cats). Doctoral thesis. Veterinary Faculty, Ludwig-Maximilians-University, Munich.
12. Krehl WA, Cowgil GR \& Whedon C (1955) Non-deleterious effects of polyoxyethylene esters in the nutrition of rats and cats. J Nutr 55, 35-61.

13. Laflamme DP \& Ballum JM (2002) Effect of age on maintenance energy requirements of adult cats. Compend Cont Educ Pract Vet 24, 82.

14. Miller SA \& Allison JB (1958) The dietary nitrogen requirements of the cat. $J$ Nutr $\mathbf{6 4}, 493-501$.

15. Taylor EJ, Adams C \& Neville R (1995) Some nutritional aspects of ageing in dogs and cats. Proc Nutr Soc 54, 645-656.

16. German AJ (2006) The growing problem of obesity in dogs and cats. J Nutr 136, 1940S-1946S.

17. Kienzle E, Edtstadtler-Pietsch G \& Rudnick R (2006) Retrospective study on the energy requirements of adult colony cats. J Nutr 136, 1973S-1975S.

18. Harper EJ, Stack DM, Watson TDG, et al. (2001) Effect of feeding regimens on bodyweight, composition and condition score in cats following ovariohysterectomy. J Small Anim Pract 42, 433-438.

19. Peachey SE, Harper EJ \& Dawson JM (1999) Effect of ageing on resting energy expenditure in cats. Vet Rec 144, 420.

20. Nguyen P, Mariot S, Martin L, et al. (2000) Assessment of energy expenditure with doubly-labelled water in adult cats. Compend Cont Educ Pract Vet 22, 96.

21. Scarlett JM, Donoghue S, Saidla J, et al. (1994) Overweight cats: prevalence and risk factors. Int $J$ Obes 18, Suppl. 1, S22-S28.

22. Kanchuk ML, Backus RC, Calvert CC, et al. (2003) Weight gain in gonadectomized normal and lipoprotein lipase-deficient male domestic cats results from increased food intake and not decreased energy expenditure. J Nutr 133, 1866-1874.

23. Flynn MF, Hardie EM, \& Armstrong PJ (1996) Effect of ovariohysterectomy on maintenance energy requirements in cats. J Am Vet Med Assoc 209, 1572-1581.

24. Martin L, Siliart B, Dumon H, et al. (2001) Leptin, body fat content and energy expenditure in intact and gonadectomized adult cats: a preliminary study. J Anim Physiol Anim Nutr 85, 195-199.

25. Fettman MJ, Stanton CA, Banks LL, et al. (1997) Effects of neutering on bodyweight, metabolic rate and glucose tolerance of domestic cats. Res Vet Sci 62, 131-136.

26. Nguyen PG, Dumon HJ, Siliart BS, et al. (2004) Effects of dietary fat and energy on both bodyweight and composition after gonadectomy in cats. Am J Vet Res 65, 1708-1713.

27. Hoenig M \& Ferguson DC (2002) Effects of neutering on hormonal concentrations and energy requirements in male and female cats. Am J Vet Res 63, 634-639.

28. Nguyen P, Dumon H, Frenais R, et al. (2001) Energy expenditure and requirement assessed using three different methods in adult cats. Compend Cont Educ for Pract Vet 23, 86.

29. Leray V, Dumon H, Martin L, et al. (2006) No effect of conjugated linoleic acid or Garcinia cambogia on fat-free mass, and energy expenditure in normal cats. J Nutr 136, 1982S-1984S.

30. Lester T, Czarnecki-Maulden G \& Lewis D (1999) Cats increase fatty acid oxidation when isocalorically fed meat-based diets with increasing fat content. Am J Physiol Regul Integr Comp Physiol 46, R878-R886.

31. Prola L, Dobenecker B \& Kienzle E (2006) Interaction between dietary cellulose content and food intake in cats. J Nutr 136, 1988S-1990S.

32. Parkman AL, Michel KE, Erswell KE, et al. (2001) How many calories do pet cats really need? Compend Cont Educ Pract Vet 23, 85.

33. Riond JL, Stiefel M, Wenk C, et al. (2003) Nutrition studies on protein and energy intake in domestic cats. J Anim Physiol Anim Nutr 87, 221-228. 
34. Hill RC (2006) Challenges in measuring energy expenditure in companion animals: a clinician's perspective. J Nutr 136, 1967S-1972S.

35. Appleton DJ, Rand JS, Priest J, et al. (2004) Dietary carbohydrate source affects glucose concentrations, insulin secretion, and food intake in overweight cats. Nutr Res 24, 447-467.

36. Aub JC, Foremann F \& Bright EE (1922) The effect of adrenalectomy upon the total metabolism of the cat. Am J Physiol 61, 326-348.

37. Ballevre O, Anantharaman-Bar G \& Gicquello P (1994) Use of doubly-labeled water method to assess energy expenditure in free living cats and dogs. J Nutr 124, 2594S-2600S.

38. Benedict FG (1938) Vital Energetics, publication no. 513. Washington, DC: Carnegie Institution of Washington.

39. Burger IH, Blaza SE \& Kendall PT (1984) The protein requirement of adult cats for maintenance. Feline Prac 4, 8-14.

40. Carpenter TM (1944) The effects of sugars on the respiratory exchange of cats. J Nutr 28, 315-323.

41. Green AS, Ramsey JJ, Villaverde C, et al. (2008) Cats are able to adapt protein oxidation to protein intake provided their requirement for dietary protein is met. $J$ Nutr 138, 1053-1060.

42. Hauschild C (1993) Energetische Untersuchungen sum Erhaltungsbedarf von adulten Katzen (Investigations on maintenance energy requirements of cats). Doctoral Thesis, Freie Universitaet, Berlin.

43. Hoenig M, Thomaseth K, Waldron M, et al. (2007) Insulin sensitivity, fat distribution, and adipocytokine response to different diets in lean and obese cats before and after weight loss. Am J Physiol Regul Integr Comp Physiol 292, R227-R234.

44. Kendall PT, Blaza SE \& Smith PM (1983) Comparative digestible energy requirements of adult beagles and domestic cats for body weight maintenance. J Nutr 113, 1946-1955.

45. Laeuger S (2001) Der Energieumsatz von Katern vor und nach der Kastration (The energy expenditure of male cats before and after neutering). Doctoral Thesis, University of Zurich.
46. Nguyen P, Mariot S, Martin L, et al. (2000) Assessment of energy expenditure with doubly labelled water in adult cats. Compend Cont Educ Pract Vet 22, 96.

47. Nguyen P, Dumon H, Martin L, et al. (2002) Weight loss does not influence energy expenditure or leucine metabolism in obese cats. J Nutr 132, 1649S-1651S.

48. Nguyen P, Leray V, Dumon H, et al. (2004) High protein intake affects lean body mass but not energy expenditure in nonobese neutered cats. $J$ Nutr 134, 2084S-2086S.

49. Radicke B (1995) Effect of nutrient composition of complete diets on maintenance energy requirements, energy accretion and energy utilisation for accretion and crude protein requirements of adult cats (in German). Doctoral Thesis, Freie Universitaet, Berlin.

50. Skultety FM (1969) Alterations of caloric intake in cats following lesions of the hypothalamus and mid brain. Ann $N$ $Y$ Acad Sci 157, 867-874.

51. Stiefel M (1999) Einfluss dreier unterschiedlicher Diäten auf den Energie- und Proteinstoffwechsel adulter Katzen unter spezieller Berücksichtigung der physischen Aktivität (Effect of three different diets on energy and protein metabolism of adults cats with special consideration of physical activity). Doctoral Thesis, University of Zurich.

52. Tennant B (1998) Assessment of energy expenditure in cats using indirect calorimetry. J Anim Physiol Anim Nutr 80, $60-62$.

53. Villaverdere C, Green AS, Asami DK, et al. (2007) Changes in energy expenditure associated with weight loss or gain in cats. Compend Cont Educ Pract Vet 29, 60.

54. Villaverde C, Ramsey JJ, Green AS, et al. (2008) Energy restriction results in a mass-adjusted decrease in energy expenditure in cats that is maintained after weight regain. $J$ Nutr 138, 856-860.

55. Wichert B, Müller L, Gebert S, et al. (2007) Additional data on energy requirements of young adult cats measured by indirect calorimetry. J Anim Physiol Anim Nutr 91, 278-281. 